Lazar ĐOKOVIĆ, student

Pravni fakultet,

Univerzitet u Beogradu
Studentski rad

UDK: 316.64:351.74(497.11)

Primljeno:31.3.2020.

Prihvaćeno:5.5.2020.

https://doi.org/10.47152/rkkp.58.1.2.10

\title{
STAVOVI GRAĐANA O RADU POLICIJE - OCENA PRIMENE STRATEGIJE POLICIJE U ZAJEDNICI U REPUBLICI SRBIJI
}

Predmet istraživanja ovog rada su stavovi i iskustva ispitanika $u$ vezi sa njihovim susretima sa policijskim službenicima. Istraživanje je sprovedeno u cilju utvrđivanja da li su ispunjeni uslovi za razvijanje partnerskog odnosa između društvene zajednice i policije, kakva je priroda tog odnosa, te da li dolazi do valjane primene strategije policije u zajednici - kao zvanične u Republici Srbiji.

Utvrđeno je da građani uglavnom nemaju poverenja u policiju, da uglavnom nisu upoznati sa radom i planovima rada policije, kao $i$ da je visok procenat onih koji imaju negativna iskustva sa policijskim službenicima i zamerke na rad policije. Sa druge strane, zapažena je inertnost građana kada se radi o predlaganju promena i preduzimanju prvih koraka ka kreiranju zdravog odnosa sa policijom. Naposlet$k u$, autor zaključuje da se strategija policije u zajednici ne primenjuje u adekvatnoj meri, kao i da ima mesta za promene kako na strani policije, tako i na strani društvene zajednice u cilju razvijanja kvalitetnog partherskog odnosa i stvaranja uslova za valjanu primenu ove strategije.

Ključne reči: policija u zajednici, formalna socijalna kontrola kriminaliteta, poverenje u policiju, partnerstvo policije i zajednice, prevencija.

* e-mail: lazarsdjokovic@gmail.com 


\section{Uvod}

U skladu sa Nacionalnim programom za integraciju Republike Srbije u Evropsku uniju, a na osnovu pozitivnog zakonodavstva, Vlada Republike Srbije je 2013. godine donela Strategiju policije u zajednici. ${ }^{4}$ Navedena strategija je doneta kao posledica preporuka iz priručnika i drugih dokumenata Organizacije za evropsku bezbednost i saradnju (OEBS), ali i dugoročnih reformi MUP-a koje su joj prethodile. Kao cilj implementacije ove strategije izdavajaju se: smanjenje konflikata, obezbeđenje bolje dostupnosti pravdi i adekvatan odgovor na bezbednosne potrebe i zahteve građana, uz njihovu podršku radu policije.

Od donošenja strategije do nastanka ovog rada usvojeno je nekoliko Akcionih planova za primenu strategije, Priručnika za njenu primenu, te je sprovedeno i nekoliko studija o radu policije u zajednici. U navedenim dokumentima se predviđaju različite promene na planu organizacije policije, sprovođenja i transparentnosti njenih aktivnosti. ${ }^{5}$

Ovaj rad će se pored osvrta na opšte karakteristike strategije policije u zajednici (Community policing), baviti i time - da li i u kojoj meri u Republici Srbiji, gotovo dvadeset godina posle početka reformi policije, a sedam godina posle usvajanja strategije dolazi do njene primene i da li su ispunjeni uslovi za ostvarenje ciljeva ove strategije.

U radu će biti prikazani podaci do kojih se došlo pri ispitivanju građana o njihovim stavovima prema policiji i informisanosti o radu policije, o poverenju $u$ policiju (kao osnovu razvijanja partnerskog odnosa policije i društvene zajednice), te o osećanjima koja se kod građana javljaju pri susretu sa policijskim službenicima. Osim navedenog, ukazaćemo na neke primedbe na rad i preporuke za poboljšanje rada policije do kojih se pri ispitivanju građana došlo.

\section{Uopšteno o strategijama delovanja policije}

Tri ključna organa formalne socijalne kontrole kriminaliteta su policija, sudovi i zavodske ustanove (Ignjatović 2018: 152). Našu pažnju u ovom radu okupira policija kao najširi aparat formalne socijalne kontrole.

U evoluiranju policije se mogu uočiti tri značajne faze:

4 “Službeni glasnik RS”, br. 43/2013.

5 Dostupno na: http://www.mup.gov.rs/wps/portal/sr/baner sadrzaj/!ut/p/z1/fY29CsIwFEZfJ SCdb1rB4Nil1VIXoli zhNs2SGK4 UtFfHozODt9HDicDxQ0oAhf9oHBDoQ-813tdJrts8O25HV5FQXPT6 Iq5EUcU5mBXG Z91np TyyC oQP23Y866aVI5qG6gYN4BmnFtve20j5eU8BbJzL9hC bzB13CxyEq1iFbWWTTUyQYn-XtC0gQ7uE!/, pristupljeno 22.02.2020. 
- politička era (1840-1930) - policija čvrsto povezana sa političkim strukturama i zavisna od volje vladara, a policijski službenici svoj interes temelje na zadovoljavanju političkih elita, a ne na zadovoljavanju interesa opšte bezbednosti;

- era reforme (1930-1980) - ili progresivna era. U ovoj fazi se policija distancira od politike, što se na praktičnom nivou sprovodi na različite načine. ${ }^{6}$ Policija postaje nepristrasan organ za sprovođenje zakona, a kontrola kriminaliteta se zasniva samo na primeni represivnih mera na učinioce krivičnih dela;

- era zajednice (1980-danas) - policija se posmatra kao servis građana u širem smislu, decentralizovana je i okrenuta ka rešavanju problema u zajednici, prevenciji kriminaliteta i razvijanju čvršćih odnosa sa zajednicom (Miller, Hess, 2005: 9-17).

Prema odredbi člana 30. pozitivnog Zakona o policiji ${ }^{7}$ svi policijski poslovi - kao zakonom uređeni poslovi koje sprovode policijski službenici, obavljaju se u cilju ostvarivanja bezbednosne zaštite života, prava i sloboda građana, zaštite imovine, kao i podrške vladavini prava. Prevencija kriminaliteta i unapređenje bezbednosti u zajednici se nalaze na prvom mestu pri nabrajanju policijskih poslova (vidi: član 30. stav 3.), iz čega bi se mogla tumačiti namera zakonodavca da naročito ukaže na prioritet obavljanja tih policijskih poslova u odnosu na ostale.

Iako sintagma borba protiv kriminaliteta na prvi pogled ukazuje na represivno delovanje, na ovom planu je preventivno policijsko delovanje naročito značajno. ${ }^{8}$ U naučnoj i stručnoj javnosti preovlađuje stav da je veći značaj preventivnog policijskog delovanja na kriminalitet u odnosu na represivni (Ignjatović, 2002: 90-91). Svako represivno delovanje podrazumeva sistem aktivnost koje su usmerene na rešavanje konkretnog slučaja, tj. na privođenje pravdi učinioca onog ponašanja koje je društveno neprihvatljivo, a u pogledu kojeg je policija nadležna. Ipak, ovakav pristup rešavanju problema ne može zadovoljiti bezbednosne potrebe u zajednici. Nasuprot represiji, preventivno delovanje po-

6 U literaturi se navodi kao primer da je u Los Anđelesu poziciju šefa policije odlikovalo to da predstavlja servis građana, a svako ko aplicira na tu poziciju morao je položiti određeni test građanske službe; Takođe, u nekim mestima je šef policije biran doživotno od strane građanskih komisija (Miller, Hess, 2005: 10).

7 “Službeni glasnik RS”, br. 6/2016, 24/2018 i 87/2018.

8 Palmiotto, navodeći neke od definicija prevencije kriminaliteta, ukazuje na definiciju National Crime Prevention Institute (1986) - da su to svi oni napori usmereni na direktnu kontrolu kriminaliteta koji smanjuju ekološke mogućnosti nastanka kriminaliteta. U svetlu široke primene strategije delovanja policije u zajednici, autor ukazuje da odgovornost za prevenciju nije samo na policiji, već i na lokalnoj zajednici (Palmiotto, 2011: 153). 
drazumeva aktivnosti usmerene na sprečavanje nastanka ekscesnog ponašanja, što je svakako ono što građani očekuju kao posledicu rada policije, ali i kao osnovni preduslov za stvaranje osećaja bezbednosti kod svakog pojedinca. ${ }^{9}$

Usled povećanja nivoa straha od kriminaliteta, te nezadovoljstva društvene zajednice radom policije, nastale su nove koncepcije policijskog delovanja čije je osnovno obeležje čvršća povezanost policije i građana. Među novim koncepcijama se izdvajaju: teorija razbijenih prozora (Broken Windows Theory), pristup nulte tolerancije (Ziro Tolerance Strategy), strategija problemski orijentisanog policijskog delovanja (POP - Problem Oriented Policing) i ona koja će svoju primenu, bar formalno naći i u Republici Srbiji - strategija policije u zajednici (Community policing) (Nikač 2019: 69-73). Navedene koncepcije nisu međusobno potpuno nezavisne, naprotiv - upravo osnovne postavke koncepta razbijenih prozora, te strategije problemski orijentisanog policijskog delovanja predstavljaju poreklo strategije policije u zajednici, a istovremeno i njene varijacije sa brojnim zajedničkim osobinama (Oliver, 2000: 3-39).

\section{Osnovne teorijske postavke strategije policije u zajednici}

Pri definisanju policije u zajednici ${ }^{10}$ može se navesti da je ona policijska filozofija koja podrazumeva na komunikaciji zasnovanu i strategiju orijentisanu ka rešavanju osnovnih uzroka kriminaliteta, nereda i straha od kriminaliteta (McLaughlin, Muncie, 2006: 41). ${ }^{11} \mathrm{Na}$ osnovu ove, ali i drugih definicija strategije policije u zajednici, mogu se utvrditi neka njena obeležja. Pre svega - community policing je filozofija, a ne samo izolovani program; ona donosi stalnu obavezu prema zajednici; proširuje policijsku misiju izvan kontrole kriminaliteta; obezbeđuje sveobuhvatan, dostupan, personalizovan i decentralizovan rad policije; fokusira se na rešavanje problema; povećava odgovornost; deluje i preventivno i po pozivu građana (Bucqueroux, Trojanowicz, 1998, prema: Roberg, Crank, Kuykendall, 2004:75).

9 Postoje tri modela preventivnog delovanja na kriminalitet: samostalno preventivno postupanje građana u lokalnoj zajednici; preventivno postupanje policije na bezbednosnom sektoru uz delimičnu saradnju sa građanima; saradnja građana i policije na prevenciji kriminaliteta u lokalnoj zajednici (Krivokapić, 2002: 223).

10 O razrešavanju terminoloških dilema vidi: Simonović (2006: 40-42).

11 Na sličan način je strategija delovanja policije u zajednici određena i u dokumentu SEESAC-a(South Eastern and Eastern Europe Clearinghouse for the Control of Small Arms and Light Weapons) iz 2006. godine $u$ kojem su istaknuti filozofija i principi ove stratetije - Community policing je istovremeno filozofija (način razmišljanja) i organizaciona strategija koja dozvoljava policiji i društvenoj zajednici da rade zajedno na novim rešenjima problema kriminaliteta i pitanja bezbednosti, a sve kako bi se poboljšao život svakog pojedinca u društvenoj zajednici (SEESAC, 2006: 3). 
Koncept policije u zajednici se razvija u četiri dimenzije - filozofska, strateška, taktička i organizaciona. Element svake od njih jeste postojanje odnosa određenog kvaliteta između policije i građana - to je odnos koji je drugačiji u od tradicionalnog pristupa i to u smeru profilaktičnog pristupa identifikovanju, definisanju i rešavanju problema u lokalnoj zajednici. ${ }^{12}$

S obzirom da partnerstvo podrazumeva međusobnu jednakost partnera, to bi na delikatnom polju kriminaliteta podrazumevalo da policija i društvena zajednica zajednički odlučuju koja ponašanja je i na koji način neophodno korigovati, te na koja ponašanja treba posebno obratiti pažnju. Prema reči Simonovića, postizanje partnerstva između policije i zajednice je fundamentalni cilj primene strategije i zasniva se na tome da građani zajedno sa policijskim službenicima definišu bezbednosne potrebe i probleme, te da utiču na donošenje policijskih odluka. "Pri uspostavljanju partnerstva, policija postaje neraskidivi deo lokalne zajednice, zavisna od zajednice, kao što je i zajednica zavisna od policije" (Simonović, 2006: 43).

Preduslov za nastanak partnerskog odnosa je da građani steknu poverenje u policiju (Vuković, 2008: 136). Sticanje poverenja je dugotrajan i zahtevan proces u kojem je cilj da svest pojedinaca prema policiji evoluira iz faze potpunog nepoverenja i straha u fazu u kojoj građani na osnovu, na iskustvu utemeljenih stavova, veruju policiji. U teoriji se mogu pronaći mišljenja o najsnažnijim preprekama u sticanju poverenja građana u policiju, a samim tim i u razvoju partnerskog odnosa; Tako se zaključuje da su prekomerna upotreba sile, korumpiranost, nepristojnost, autoritarizam i politizovanost policije najčešći razlozi zbog kojih se ne može uspostaviti odnos partnerstva između policije i lokalne zajednice (Kappeler, Gaines, 2015: 153-160).

Ne treba zanemariti da je jedan od uslova za nastanak partnerstva postojanje određenog stepena kohezije u društvenoj zajednici. Uprkos tome što postoje brojne definicije društvene kohezije, autori se slažu kad je reč o njenim sastavnim elementima: prvi- ljudi u zajednici dele iste vrednosti, poštuju jedni druge i imaju zajednički identitet; drugi - ljudi u zajednici dele ciljeve i odgovornost i pokazuju volju da sarađuju međusobno (Peak, 2013: 34).

12 U literaturi se navodi da postoje tri faze razvoja strategije policije u zajednici (sa osvrtom na SAD): Prva faza (faza inovacije) od 1979. do 1986. koja je okarakterisana kao svojevrsna posledica uticaja teorije slomljenih prozora kombinovana sa strategijom rešavanja problema. Ova faza je zapravo sačinjena od izolovanih primera eksperimentalne primene ove strategije u svega nekoliko urbanih naselja u SAD-u. Druga faza - faza difuzije, od 1987. do 1994. godine, podrazumeva logičnu posledicu prvih pokazatelja uspeha eksperimenata iz faze inovacija, te dolazi do primene različitih programa na širem polju koji podrazumevaju širenje tada postojećih i stvaranje novih organizacionih jedinica policije. Naposletku, faza institucionalizacije koja trenutno traje je pokazatelj široke rasprostranjenosti ovog modela policijskog delovanja (Peak, 2013: 53-54; Miller, Hess, 2005: 22-23). 
Community policing se zasniva na: konsultovanju policije sa zajednicom (spoznaja ponašanja koja, prema stavu građana predstavljaju opasnost po njihovu bezbednost); odgovaranje na pozive građana što revnosnije ${ }^{13}$; mobilizacija javnosti da samoinicijativno preduzimaju korake ka rešavanju problema (uz saradnju sa policijom) (Bayley, 2006: 59-60). ${ }^{14}$

\section{Motivi, rezultati i ciljevi strategije}

Prema rečima Silvermana, ranije su policijske jedinice češće bile ocenjivane prema njihovoj produktivnosti nego prema njihovom stvarnom uticaju na kriminalitet. ${ }^{15}$ "Iako je potreba za promenama jačala, policijska birokratija od vrha prema dnu organizacije, rigidno slojevita i stroko fragmentisana, pod uticajem političkih okolnosti se dugo suprotstavljala promenama" (Silverman, 1999: 18). Slično stanje se moglo beležiti i na našim prostorima; Tako Simonović ukazuje da su opšte karakteristike policije u zemljama socijalističkog društvenog uređenja bile: dominantna orijentacija policije na zaštitu političkog režima; primarno represivno delovanje u odnosu na ponašanja kojima se narušavaju zakoni; otežano uvođenje profesionalizma u policiju; dominantan politički uticaj i policija udaljena od građana i potpuna zapostavljenost preventivne delatnosti (Simonović, 2006: 17).

Takođe, tradicionalni koncept birokratizovane, militarističke, ka režimu orijentisane i od građana udaljene policije koju je karakterisao gotovo isključivi represivni pristup kriminalitetu, bilo je neophodno promeniti (Simonović, 2005: 75). Od Srbije se početkom ovog stoleća, sa aspekta međunarodne zajednice očekivalo da sprovede ozbiljne društveno-ekonomske promene, da na normativnom i praktičnom nivou dovede do jačanja vladavine prava, a da se rad policije usmeri na potrebe građana. MUP Republike Srbije je od 2001. godine počeo sa sprovođenjem priprema za uvođenje modela policije u zajednici i preduzeo različite mere na planu preventivnog delovanja policije (Nikač 2019, 68).

Konačno, strategija Vlade Republike Srbije navodi, kao osnovni motiv razvoja ove strategije, unapređenje saradnje i zajednički rad policije i zajednice.

13 U praksi se to može sprovoditi na više načina: npr. veći broj manjih policijskih stanica, pešačke patrole...

14 U teoriji se navode i osnovni principi na kojima se zasniva community policing; Nikač navodi nekoliko osnovnih principa - promene, vizija, vođstvo, rešavanje problema, partnerstvo, jednakost, poverenje, veća ovlašćenja policijskih službenika, usluge i uzajamna odgovornost policije i zajednice" (Nikač, 2008: 519-520).

15 Npr. uspešnost rada policijskih patrola je bila ocenjivana prema tome na koliko poziva uznemirenih građana su odgovarale, bez obzira na to o kakvom se ponašanju radilo, te da li su lica procesuirana. 
$\mathrm{Na}$ ovom mestu ističemo da su različite aktivnosti rezultovale bar formalnim promenama u pristupu policije suzbijanju kriminaliteta i to upravo donošenjem Strategije policije u zajednici 2013. godine, zatim usvajanjem Akcionog plana za sporovođenje strategije policije u zajednici za 2015. i 2016. godinu ${ }^{16}, \mathrm{i}$ naposletku usvajanje Akcionog plana za sprovođenje strategije razvoja MUP-a za period 2018-2023. godine čija je treća strateška oblast posvećena policiji kao servisu građana. ${ }^{17}$

\subsection{Rezultati i ciljevi primene strategije}

Rezultati primene strategije policije u zajednici se ogledaju u: povećanju efikasnosti u suzbijanju kriminaliteta, razvoju prevencije orijentisanjem na probleme koji uzrokuju kiminalitet, veće zadiranje u tamnu brojku kriminaliteta... (Nikač, 2019: 65).

Nasuprot rezultatima primene strategije policije u zajednici, za nas su u ovom radu, posebno značajni ciljevi primene ove strategije kao kvalitativne promene na planu odnosa između policije i društvene zajednice, ali i na planu kvaliteta života građana u zajednici.

Ciljeve strategije policije u zajednici možemo podeliti na neposredne i posredne. Neposredni ciljevi su: veći kvalitet policijskih usluga; dostupan i ravnopravan pristup pravdi za sve, poboljšani odnosi između policije i zajednice, zdrava strateška partnerstva, održiva rešenja bezbednosnih problema zajednice... (Nikač 2019, 66). Sa druge strane, svi neposredni ciljevi treba da budu ispunjeni zarad ostvarenja posrednog, načelnog cilja - poboljšanja kvaliteta života građana.

Primena strategije policije u zajednici podrazumeva da od nje ima korist $i$ društvena zajednica, ali i policija. Roberg, Crank i Kuykendall daju odgovore na pitanje - koje koristi ima zajednica, a koje policija iz primene strategije policije u zajednici. Kada uzmemo u obzir koristi koje ima društvena zajednica, mogu se navesti sledeće pogodnosti: policija se obavezuje da spreči kriminalitet, a ne samo da reaguje na njega; kontrola rada policije je na višem novu (s obzirom da je vrše i sami građani), a policajci su za svoj rad odgovorni i građanima; u skladu sa stavovima građana, policija prioritizuje određena ponašanja kao naročito socijalno pataloška i u skladu sa tim planira svoje postupanje. Sa druge strane, policija

16 Zaključak o usvajanju Akcionog plana za primenu Strategije policije u zajednici za 2015. i 2016. godinu, "Službeni glasnik RS”, br.70/2015-79.

17 Dostupno na:http:/www.mup.gov.rs/wps/wcm/connect/671ccefc-44aa-4687-9959-cbe7af46e904/ PDF_LAT_A.P.+strategija+razvoja + MUP+2018-23.pdf?MOD=AJPERES\&CVID=mtlSHLr pri-

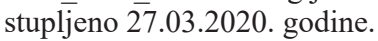


ima veću podršku od zajednice, podignut je i nivo njihove bezbednosti pri obavljanju svoje delatnosti, a sa građanima deli odgovornost za kriminalitet i nerede (Roberg, Crank, Kuykendall, 2004: 93).

\section{Empirijsko istraživanje}

\subsection{Teorijski okvir sprovedenog istraživanja}

S obzirom da su u prethodnom delu rada okvirno predstavljeni nastanak, pojam, motivi, rezultati i ciljevi strategije policije u zajednici, na ovom mestu naglašavamo da je ova strategija u proteklih gotovo pola veka u primeni u različitim državama, te da se kroz vreme menjao fokus istraživanja u ovoj oblasti. Centar interesovanja istraživača se kreće od istraživanja iskustava građana sa policijom usled primene strategije policije u zajednici, do istraživanja povezanosti kvaliteta života građana i stepena zadovoljstva radom policije (Morash, Ford, 2002: 46-50).

Skrećemo pažnju na jedno od poslednjih istraživanja u ovoj oblasti kod nas. Ono se odnosilo na stavove i iskustva 421 ispitanika - polaznika Centra za osnovnu policijsku obuku iz Beograda, 2016. i 2017. godine. U tom radu je utvrđeno da policija u Beogradu nije otvorena ka zajednici, da nije vidljiva u zajednici, te da njene aktivnosti nisu transparentne. Sa druge strane, ukazano je da ima mesta za poboljšanja na planu informisanosti građana o radu policije i bezbednosnoj problematici. Konačno, autori su zaključili da novi koncept rada policije u zajednici nije bio zastupljen u Beogradu, u vreme sprovođenja konkretnog istraživanja (Ivetić, Ivetić, 2019: 142-143).

Istraživanje predstavljeno u ovom radu je sprovedeno sa vremenskom distancom od tri godine u odnosu na prethodno, sa delimično različitim prostornim okvirom. Za vreme proteklog perioda je trebalo da dođe do primene dva Akciona plana za sprovođenje strategije, te se opravdanost ovog rada ogleda $u$ predstavljanju naučnoj i stučnoj javnosti trenutnog stanja na planu implementacije strategije policije u zajednici.

\subsection{Metodologija}

\subsubsection{Predmet istraživanja}

Predmet istraživanja su bili stavovi i iskustva građana u vezi sa njihovim susretima sa policijskim službenicima, sa poverenjem u policiju i njihovom informisanošću o radu i planovima rada policije. 


\subsubsection{Istraživački instrument}

Kao istraživački instrument korišćena je anonimna anketa sastavljena od 12 pitanja o predmetu istraživanja i 4 pitanja o ličnosti ispitanika.

Pored pitanja o polu, godini rođenja, mestu boravka i stepenu obrazovanja, ispitanicima su postavljana pitanja kojima se zahtevalo da rangiraju osećaj sopstvene bezbednosti u mestu boravka, da rangiraju osećaj poverenja u policiju, te zadovoljstva pruženim policijskim uslugama, kao i stepen upoznatosti sa radom i planovima rada policije. Ispitanicima su postavljena i četiri zatvorena - dihotomna pitanja o tome da li smatraju da se policijski službenci ponašaju jednako prema svim građanima bez obzira na pol, rasnu, versku ili drugu pripadnost; da li su nekada konsultovani od strane policajaca o svom stavu o bezbednosti u mestu boravka, odnosno o saznanjima da li u njihovoj okolini postoje naznake vršenja krivičnih dela ili drugih društveno neprihvatljivih ponašanja, kao i da li imaju zamerke na rad policije.

Ispitanicima su postavljena i pitanja o tome kako se osećaju pri neposrednom odnosu sa policijskim službenicima, odnosno kakva su im iskustva sa ponašanjem policajaca u neposrednom odnosu sa njima, uz ponuđene odgovore. Takođe, ispitanici su mogli da u slobodnoj formi iskažu u čemu se sastoje njihove zamerke na rad policije (ukoliko ih imaju), te da predlože rešenja čijom bi primenom došlo poboljšanja rada policije, a samim tim i do nastanka uslova za ostvarenje ciljeva strategije.

Odgovori su, po prikupljanju, sistematizovani, statistički obrađeni i analizirani, a rezultati analize su predstavljeni deskriptivno ili u tabelarnom prikazu.

\subsubsection{Uzorak}

Istraživanje je sprovedeno na uzorku koji se sastoji od 532 punoletna ispitanika, od kojih je 293 (51,3\%) ženskog i 259 (48,7\%) muškog pola. Uzorak je dobijen na dva načina. Prvi - uzorak grudve snega nastao je deljenjem adrese internet stranice na kojoj se nalazila anketa na društvenoj mreži Facebook, a ispitanici su po popunjavanju prosleđivali anketu svojim poznanicima; Drugi način - klasično anketiranje slučajno odabranih građana na javnim prostorima. Starosna struktura uzorka je predstavljena u tabeli br. 1 .

Tabela br. 1: Starosna struktura ispitanika.

\begin{tabular}{|l|c|c|}
\hline Okvirne godine starosti & Broj ispitanika & $\%$ \\
\hline Do 20 & 117 & 22 \\
\hline $20-30$ & 319 & 60 \\
\hline Preko 30 & 96 & 18 \\
\hline
\end{tabular}


Od ispitanika je zahtevano da ostave podatke o stepenu svog obrazovanja, a rezultati su predstavljeni u tabeli br. 2 .

Tabela br. 2: Stepen obrazovanja ispitanika.

\begin{tabular}{|l|c|c|}
\hline Stepen obrazovanja & Broj ispitanika & $\%$ \\
\hline Osnovna škola & 6 & 1.2 \\
\hline SSS & 136 & 25.6 \\
\hline VS & 39 & 7.3 \\
\hline VSS & 351 & 65,9 \\
\hline
\end{tabular}

5.2.4. Vremenski i prostorni okvir istraživanja

Ispitivanje je sprovedeno u periodu - januar - mart 2020. godine, a ispitanici su građani sa boravištem ${ }^{18}$ na teritoriji Beograda (275 građana, odnosno $51,7 \%$ ispitanika), Kragujevca (110 građana, odnosno 20,7\% ispitanika) i Novog Sada (147 građana, odnosno $27,6 \%$ ispitanika).

\subsection{Ciljevi istraživanja}

Ciljevi istraživanja su:

- spoznaja prirode i sadržine odnosa između policije i društvene zajednice;

- utvrđivanje da li su ispunjeni uslovi za stvaranje partnerskog odnosa, kao jednog od osnovnih uslova za adekvatnu primenu strategije;

- utvrđivanje da li se i u kojoj meri strategija policije u zajednici primenjuje u Republici Srbiji.

\subsection{Rezultati istraživanja}

U predstojećem delu rada prikazani su rezultati sprovedenog istraživanja uz napomene zašto su određena pitanja postavljena i kakav je značaj odgovora na ta pitanja za ocenu primene strategije u RS i za ostvarenje njenih ciljeva.

18 Jedan od razloga iz kojeg se zahtevalo od ispitanika da ostave podatak o svom borativštu je da se, pre svega, akcenat stavi na faktičko stanje - kao stvarni boravak na određenom mestu (ne ograničavajući ispitanike da navedu mesto prebivališta u pogledu kojeg u nekim slučajevima može da postoji samo ispunjenost formalnog uslova, $\mathrm{tj}$. da je lice prijavilo svoje prebivalište $\mathrm{u}$ određenom mestu, a da zapravo duži vremenski period (nekada i nekoliko godina) boravi na drugom mestu). 


\subsubsection{Kako biste rangirali sopstveni osećaj bezbednosti}

u mestu gde boravite?

Značajan pokazatelj bezbednosti u lokalnoj zajednici je sopstveni osećaj bezbednosti svakog pojedinca koji tu zajednicu, kao sistem međusobno povezanih elemenata čini. Ispitanicima je predočena skala od 1 (ne osećam se bezbedno) do 5 (osećam se potpuno bezbedno) na kojoj je, zaokruživanjem odgovarajućeg broja trebalo da iskažu sopstveni osećaj bezbednosti. Rezultati su prikazani u tabeli br. 3 .

Tabela br. 3: Rangiranje sopstvenog osećaja bezbednosti.

\begin{tabular}{|l|c|c|c|c|c|}
\hline Nivo bezbednosti & 1 & 2 & 3 & 4 & 5 \\
\hline Odgovori ispitanika u procentima & 3,4 & 17,7 & 31,8 & 31 & 16,1 \\
\hline
\end{tabular}

\subsubsection{Stvaranje partnerskog odnosa između zajednice i policije}

Kako je ranije ukazano, za ostvarivanje čvrstog partnerstva između policije i zajednice neophodno je da građani imaju poverenje u policiju. Iz tog razloga, od ispitanika je zahtevano da rangiraju osećaj poverenja u policiju od 1 (nemam poverenja) do 5 (imam poverenja). Rezultati su prikazani u tabeli br. 4.

Tabela br. 4: Ranigranje osećaja poverenja u policiju.

\begin{tabular}{|l|c|c|c|c|c|}
\hline Stepen osećaja poverenja & 1 & 2 & 3 & 4 & 5 \\
\hline Odgovori ispitanika u procentima & 12,6 & 27,4 & 32,1 & 19,6 & 8,3 \\
\hline
\end{tabular}

Da bi građani mogli imati poverenja u policiju potrebno je da budu zadovoljni radom policije u mestu u kojem borave. U vezi sa zahtevom da rangiraju sopstveno zadovoljstvo radom policije $25,2 \%$ ispitanika je odgovorilo da je $u$ potpunosti zadovoljno ili uglavnom zadovoljno radom policije u mestu u kojem borave, a 34,2\% ispitanika je odgovorilo da uopšte nije zadovoljno, odnosno da uglavnom nije zadovoljno radom policije. ${ }^{19}$

Informisanost građana o radu policije je neophodna jer građani zajedno sa policijom, kao što smo napred ukazali, treba da utvrde koje ponašanje i kojih pojedinaca je opasno po bezbednosne prilike u zajednici. Takođe, građani moraju biti upućeni u način na koji policija vrši i planira da vrši suzbijanje kriminaliteta, te da iskažu svoje stavove o tome. Zarad utvrđivanja postojanja i ovog konstitutivnog elementa partnerskog odnosa, od ispitanika je zahtevano da rangiraju svoju informisanost o radu i planovima rada policije. Tako je 90 građana, odnosno

\footnotetext{
$1940,6 \%$ ispitanika nije bilo sigurno - tj. zaokružilo je broj 3.
} 
oko $17 \%$ ispitanika odgovorilo da je u potpunosti upoznato ili uglavnom upoznato sa radom i planovima rada policije, ali je sa druge strane 322 građanina $(60,5 \%$ ispitanika) odgovorilo da uopšte nije informisano, odnosno da uglavnom nije informisano o radu i planovima rada policije.

$\mathrm{Na}$ osnovu odredaba pozitivnog zakonodavstva, te Ustava Republike Srbije, zabranjena je diskriminacija po bilo kom osnovu. ${ }^{20} \mathrm{U}$ skladu sa navedenim, neophodno je očekivati da pol, rasna, verska ili kakva druga pripadnost ne smeju predstavljati odlučujuće kriterijume za različito postupanje policijskih službenika prema građanima. Jednako postupanje policije prema građanima i jednaka dostupnost pravdi svima, neki su od ključnih uslova za razvijanje osećaja poverenja građana u policiju. Iz napred navedenih razloga, ispitanciima je postavljeno zatvoreno dihotomno pitanje - Da li smatrate da se policija ponaša jednako prema svim građanima, bez obzira na pol, rasnu, versku ili drugu pripadnost? Potvrdan odgovor na postavljeno pitanje dalo je 156 građana, odnosno $29,3 \%$ od ukupnog broja ispitanika, dok je 376 građana, odnosno 70,7\% ispitanika svojim odgovorom navelo da smatra da policija ne postupa jednako prema svim građanima.

$\mathrm{Na}$ ovom mestu treba napomenuti da se u predmetnoj anketi našlo i pitanje otvorenog tipa gde su ispitanici imali mogućnost da u slobodnoj formi ukažu na zamerke koje imaju na rad policije (ukoliko ih imaju); među odgovorima se relativno često može naći zamerka koja se upravo odnosi na nejednako postupanje policije prema građanima. ${ }^{21}$

\subsubsection{Partnerski odnos društvene zajednice i policije u praksi}

Ispitanicima je postavljeno pitanje - Da li Vas je nekada policijski službenik konsultovao da ukažete da li se u Vašoj okolini dešavaju okolonosti koje bi mogle da ukažu na vršenje krivičnog dela ili drugog društveno neprihvaljivog ponašanja? Odgovori na navedeno pitanje ukazuju na sadržinu odnosa između društva i policije. Rezultati do kojih se došlo su sledeći: potvrdan odgovor na postavljeno pitanje dalo je 125 građana, odnosno 23,5\% ispitanika, a negativno je odgovorilo 407 građana, odnosno 76,5\% ispitanika.

Drugo pitanje postavljeno ispitanicima, takođe u vezi sa sadržinom odnosa sa policijom je bilo nešto uopštenijeg tipa - Da li Vas je nekada policijski služ-

20 Vidi čl. 21. Ustava Republike Srbije, Službeni glasnik RS, br. 98/2006.

21 Svaki peti ispitanik koji je bio voljan da u otvorenoj formi ukaže na zamerke koje ima na rad policije (od ukupno 94 ispitanika koji su na ovo pitanje ostavili odgovor) je naveo da se policijski službenici ne ponašaju jednako prema svim građanima, te da presudnu ulogu u odlučivanju na koji način će postupati u konkretnom slučaju imaju poznanstva iz sfere privatnog života ili određene predrasude. 
benik konsultovao da iskažete Vaš stav o bezbednosti u mestu u kojem boravite? Na postavljeno pitanje je 451 građanin, odnosno $84,8 \%$ ispitanika dalo negativan odgovor, a 81 , odnosno $15,2 \%$ njih je potvrdno odgovorilo.

Kako je ranije napomenuto, svaki pojedinac iz svog susreta sa policijskim službenikom stiče određeni utisak koji, u zbiru sa utiscima svih pojedinaca, predstavlja značajni pokazatelj prirode odnosa društva i policije. Ispitanicima su, iz napred navedenog razloga postavljena sledeća dva pitanja, sa ponuđenim odgovorima od kojih su mogli da odaberu po jedan, ali im je ostavljena mogućnost da dopišu za njih specifičan odgovor.

Kako se osećate pri neposrednom kontaktu sa policajcem? Rezultati su prikazani u tabeli br. 5 .

Tabela br. 5: Osećanja ispitanika pri kontaktu sa policajcem.

\begin{tabular}{|l|c|c|}
\hline Ponuđeni odgovor & Broj građana & $\%$ \\
\hline Osećam se bezbedno & 78 & 14,7 \\
\hline Osećam se uplašeno & 52 & 9,8 \\
\hline Osećam se neprijatno & 133 & 25 \\
\hline Ravnodušan/na sam & 201 & 37,7 \\
\hline Uglavnom pokušavam da izbegnem neposredan kontakt $^{22}$ & 65 & 12,2 \\
\hline Drugo $^{22}$ & 3 & 0,6 \\
\hline
\end{tabular}

Kakva su Vaša iskustva sa ponašanjem policajaca u kontaktu sa Vama? Rezultati su prikazani u tabeli br. 6.

Tabela br. 6: Ponašanje policajca prema ispitanicima.

\begin{tabular}{|l|c|c|}
\hline Ponuđeni govor & Broj građana & $\%$ \\
\hline Predusretljivi & 51 & 9,6 \\
\hline Arogantni & 130 & 24,4 \\
\hline Ljubazni & 88 & 16,5 \\
\hline Zainteresovani & 71 & 13,4 \\
\hline Nezainteresovani & 84 & 15,8 \\
\hline Nisam imao/la neposredan konktakt & 103 & 19,4 \\
\hline Drugo & 5 & 0,9 \\
\hline
\end{tabular}

22 Npr. ,zavisi kakvog je raspoloženja policajac“. 


\subsubsection{Zamerke na rad policije}

Na pitanje o tome da li imaju zamerke na rad policije, 53,6\% ispitanika je dalo potvrdan odgovor. U cilju suštinskog sagledavanja tih zamernki, ispitanicima je ostavljena mogućost da u otvorenoj formi upišu u čemu se one sastoje. Neke od najčešćih odgovora su bili:

- nezainteresovanost policije za probleme građana,

- značajan uticaj veza koje policajci imaju sa pojedincima iz privatnog života na njihov rad,

- nejednako postupanje policajaca prema građanima,

- agresivnost i neobjektivnost pojedinih policijskih službenika.

Ispitanici su navodili i da policija radi pod uticajem političkih elita, te da se ne ponaša kao servis građana, kao i da primećuju visok stepen korupcije u radu policije.

\subsubsection{Predlozi za poboljšanje rada policije}

Ispitanicima je ostavljena i mogućnost da predlože promene u radu i organizaciji policije, što bi doprinelo uspešnijoj primeni ove strategije i svakako koristilo stručnoj javnosti.

Neki od odgovora ispitanika su: potrebno je da policijski službenici prisustvuju sastancima stanara u stambenim zgradama i na neposredan način se upoznaju sa svim, pa i bezbednosnim problemima; da policijski službenici metodom od vrata do vrata upozaju građane i na taj način iniciraju zdrav odnos sa pojedincima; potrebno je osmisliti metod građanske kontrole policije i povećati unutrašnju kontrolu; povećanje plata policijskim službenicima, te dodatna ulaganja u obrazovanje i motivaciju policijskih službenika...

\section{Zaključak i diskusija}

U ovom radu pažnja je naročito poklonjena subjektivnom osećaju ispitanika u vezi sa policijom i njenim delovanjem. Tako je $40 \%$ ispitanika odgovorilo da nema ili da uglavnom nema poverenja u policiju, a 34,2\% je odgovorilo da nije zadovoljno ili uglavnom nije zadovoljno radom policije. Ovakvi rezultati proizlaze iz iskustava ispitanika iz susreta sa policijskim službenicima. Tako je 40,2\% ispitanika negativno okarakterisalo ponašanje policajaca prema njima, a njih $34,8 \%$ je okarakterisalo svoja osećanja pri susretu sa policajcem kao negativna.

Usled obrade svih relevantnih podataka i teorijskih i strateških aspekata strategije policije u zajednici može se izvesti zaključak da u Republici Srbiji još 
uvek ne dolazi do njene primene na zadovoljavajućem nivou iako postoje određeni akti koji formalno ukazuju na rešenost države da uspešno primeni ovu strategiju (uporedi: Ivetić, Ivetić, 2019: 143). Usled toga, jasno je da ne dolazi ni do željenih promena u pogledu povećanja kvaliteta života građana.

Kada se govori o prirodi i sadržini odnosa policije i zajednice, utvrđeno je da skoro svaki drugi ispitanik ima zamerke na rad policije. Većina ispitanika nije informisana o radu i planovima rada policije i nikada nije bila konsultovana od strane policijskih službenika u vezi sa bezbednošu u svom okruženju. Takođe, $12 \%$ ispitanika je navelo da pokušava da izbegne susret, a 19,4\% nije imalo kontakte sa policijom.

Ipak, 47,1\% ispitanika je, uprkos gore navedenim stavovima o zadovoljstvu radom policije i poverenju u policiju, odgovorilo da se oseća bezbedno, odnosno uglavnom bezbedno u mestu u kojem boravi. ${ }^{23}$

Kako bi društvena zajednica trebalo da bude partner policiji u suzbijanju kriminaliteta, očekuje se da na taj način i postupa i da predlaže promene u radu policije. Iako smo napred naveli neke odgovore, na ovom mestu ukazujemo da je svega $12 \%$ ispitanika bilo voljno da ostavi bilo kakav predlog. Dakle, uočljiva je inertnost građana da se uopšte upuste u razmišljanje o tome kako da umanje svoje nezadovoljstvo radom policije i doprinesu adekvatnoj primeni strategije. Dok god se odnos društva i policije temelji na ovim i sličnim karakteristikama, ne može se govoriti o ispunjenosti uslova za razvijanje valjanog partnerskog odnosa.

Svaki policijski službenik bi trebalo da postupa u skladu sa osnovama ove strategije: pre svega da inicira što veći broj neposrednih odnosa sa građanima, a sve u cilju povećanja sopstvene informisanosti o bezbednosnoj situaciji u zajednici, ali i kako bi građani bili upoznati sa radom policije. Sa druge strane, bilo bi iluzorno govoriti o tome da policija treba da promeni svoje postupanje, ukoliko društvena zajednica, kao partner sa kojim policija mora sarađivati, ne preduzme neophodne korake sa svoje strane kako bi strategija valjano funkcionisala. Konačno, stava smo da još uvek postoji mnogo mesta za napredovanje u pogledu policije i aktivnosti koje ona preduzima, ali i u pogledu koherentnosti i samoinicijativnosti društvene zajednice.

Naposletku, ostaje da se vidi da li će u vremenu pred nama doći do preko potrebnih promena uz napomenu da se, imajući u vidu rezultate istraživanja u ovoj oblast i relativnu nekoherentnost društvene zajednice, do takvih promena ne može doći u kratkom vremenskom periodu.

23 Nelogičnost ove kontradiktornosti je manja uzimajući u obzir da su neki ispitanici obrazložili svoj odgovor tako što sopstvenu bezbednost ne cene prema aktivnostima i snazi policije, već prema sopstvenim sposobnostima da se suprotstave eventualnim opasnostima. 


\section{Literatura}

- Bayley, D. H. (2006) Changing the guard: Developing democratic police abroad. NewYork: Oxford University Press;

- Bucqueroux, B., Trojanowicz R. (1998) Community Policing - How to get started. Cincinnati: Anderson Publishing Co;

- Ignjatović, Đ. (2018) Kriminologija. Beograd: Pravni fakultet Univerziteta u Beogradu - Centar za izdavaštvo i informisanje;

- Ignjatović, Đ. (2002) Strategije policijskog delovanja i prevencija kriminaliteta. Naučno-stručno savetovanje sa međunarodnim učešćem Mesto i uloga policije u prevenciji kriminaliteta - stanje mogućnosti i perspective (str. 89-101). Beograd: Policijska akademija;

- Ivetić, M., Ivetić S. (2019) Rad policije u zajednici na području grada Beograda - stavovi polaznika osnovne policijske obuke. Bezbednost, 61 (1), str. 124-147;

- Krivokapić, V. (2002) Prevencija kriminaliteta od strane građana i policije na lokalnom području (sektoru). Naučno-stručno savetovanje sa međunarodnim učešćem Mesto i uloga policije u prevenciji kriminaliteta - stanje mogućnosti i perspective (str. 223-240). Beograd: Policijska akademija;

- Kappeler, E. V., Gaines K. L. (2015) Community Policing - A contemporary Perspective. New York: Routledge;

- McLaughlin, E., Muncie J. (2006) The sage dictionary of criminology compiled and edited by Eugene McLaughlin and John Munci. London [etc.]: Sage publication;

- Miller, S. L., Hess M. K. (2005) Community Policing - Partnerships for Problem Solving. Belmont: Wadsworth/Thomson Learning;

- Morash, M., Ford, J. K. (2002) The Move to community policing - Making Change Happen. Thousand Oaks [etc.]: Sage Publications;

- Nikač, Ž. (2019) Policija u zajednici. Beograd: Kriminalističko-policijski univerzitet;

- Nikač, Ž. (2008) Koncept “policije u zajednici” (community policing) u funkciji zaštite univerzalnih vrednosti. Međunarodno krivično pravo i ljudske slobode (str. 513-527)Tara: Udruženje za međunarodno krivično pravo.

- Oliver, M. W. (2000) Community policing : classical readings. Upper Saddle River: Prentice Hall;

- Palmiotto, J. M. (2011) Community Policing - A Police-Citizen Partnership. New York [etc.]: Routledge;

- Peak, J. K. (2013) Encyclopedia of community policing and problem solving. Los Angeles [etc.]: Sage publication 
- Roberg, R., Crank, J. \& Kuykendall, J. (2004) Policija i društvo. Sarajevo: Office of Public Affairs Embasy of the United States of America;

- SEESAC (2006) Philosophy and principles of community-based policing. Beograd, dopstupno na: http://www.seesac.org/f/docs/Community-Policing/ Philosophy-and-principles-of-community-based-policing-2003-EN.pdf, pristupljeno 17.01.2020;

- Silverman, E. (1999) NYPO battles crime: innovative strategies in policing. Boston: Northeastern University press;

- Simonović, B. (2005) Konceptualne dileme, limiti, nedoslednosti, kritike i slabosti novog koncepta rada policije u zajednici (community policing) s osvrtom na ljudska prava i slobode. U: Bejatović, S. (ur.) Slobode i prava čoveka i građanina u konceptu novog zakonodavstva Republike Srbije - Knjiga IV. Kragujevac: Pravni fakultet Univerziteta u Kragujevcu: Institut za pravne i društvene nauke, str. 75-95;

- Simonović, B. (2006) Rad policije u zajednici (Community policing). Banja Luka. MUP Republike Srpske: Uprava za policijsko obrazovanje: Visoka škola unutrašnjih poslova;

- Strategija policije u zajednici, "Službeni glasnik RS”, br. 43/2013;

- Ustav Republike Srbije, "Službeni glasnik RS“, br. 98/2006;

- Vuković, S. (2008) Strategije delovanja policije u prevenciji kriminaliteta na području lokalne zajednice. Doktorska disertacija. Beograd: Pravni fakultet Univerziteta u Beogradu;

- Zakon o policiji, "Službeni glasnik RS," br. 6/2016, 24/2018 i 87/2018;

- Zaključak o usvajanju Akcionog plana za primenu Strategije policije u zajednici za 2015. i 2016. godinu "Službeni glasnik RS", br.70/2015-79.

\section{Ostali izvori}

- http://www.mup.gov.rs/wps/portal/sr/baner-sadrzaj/!ut/p/z1/fY29CsIwFEZfJSCdb1rB4Nil1VIXo1izhNs2SGK4_UtFfHozODt9HDicDxQ0oAhf9oHBDoQ-813tdJrts8O25HV5FQXPT'6Iq5EUcU5mBXGZ91npTyyCoQP23Y866aVI5qG6gYN4BmnFtve20j5eU8BbJzL9hC_bzB13CxyEq1iFbWWTTUyQYn-XtC0gQ7uE!/, pristupljeno 22.02.2020;

- http://www.mup.gov.rs/wps/wcm/connect/671ccefc-44aa-4687-9959-cbe7af46e904/PDF_LAT_A.P.+strategija+razvoja+MUP+2018-23.pdf?$\mathrm{MOD}=\mathrm{AJPERES} \& \mathrm{CVID}=\mathrm{mtlSHLr}$, pristupljeno 27.03.2020. godine. 
Lazar ĐOКОVIĆ

Faculty of Law, UniverBelgrade, student

\section{CITIZENS' ATTITUDES ON POLICE WORK - EVALUATION OF THE IMPLEMENTATION OF THE COMMUNITY POLICING IN THE REPUBLIC OF SERBIA}

The subject of this paper is the respondents' views and experiences regarding their contacts with police officers. The research was conducted to determine whether the conditions for developing a partnership between the community and the police are fulfilled, what is the nature of that relationship, and whether the Community policing is adequately implemented in the Republic of Serbia.

It was found that citizens generally do not trust the police, that they are generally not familiar with the work and plans of police work, and that there is a high percentage of those who have negative experiences with police officers and objections to police work. On the other hand, citizens' inertia is noticeable when it comes to proposing change and taking the first steps towards creating a healthy relationship with the police. Finally, the author concludes that the community policing strategy is not being adequately implemented and that there is room for change on both the police and community side in order to develop a quality partnership and create conditions for the proper implementation of this strategy.

Key words: community policing, formal social control of crime, trust in police, partnership between police and community, prevention. 